\title{
Liability of doctors based on negligence for culpable homicide: No need to change the law concerning medical negligence or to establish special medical malpractice courts - use mediation and medical assessors instead
}

\author{
D J McQuoid-Mason, BComm, LLB, LLM, PhD \\ Centre for Socio-Legal Studies, University of KwaZulu-Natal, Durban, South Africa
}

Corresponding author: D J McQuoid-Mason (mcquoidm@ukzn.ac.za)

\begin{abstract}
Doctors' organisations have called for special legislation regarding the criminal charging of doctors for culpable homicide, and the need for special medical malpractice courts to deal with the huge increase in the number of medical malpractice cases. However, there are very few criminal prosecutions, because the prosecuting authorities generally accept that doctors do not intend to kill their patients, and are only likely to charge them for intentional or very serious deviations from the standard of a reasonably competent doctor in their profession. Doctors are also generally not held liable for mere errors of judgement. Although the call is for special legislation, the issues concerned can generally be dealt with administratively by existing legislation. For instance, the requirement of mediation before litigation could be introduced by the Chief Justice. Doctors need not fear making admissions during mediation proceedings in civil matters, because legislation provides that such admissions and evidence may not be used in subsequent civil actions. The Chief Justice can also issue a practice directive that all presiding officers must appoint medicolegal experts as assessors in medical malpractice cases. The medical profession can assist the process by arranging a panel of such experts who can be called upon to serve as assessors by the courts.
\end{abstract}

S Afr Med J. Published online 27 January 2022. https://doi.org/10.7196/SAMJ.2022.v112i3.16370

It was recently reported that a number of doctors' organisations have written to the Minister of Health requesting him to introduce a stricter test beyond mere negligence to ground prosecutions against doctors in criminal culpable homicide cases. ${ }^{[1]}$ The South African Medical Association has gone further and requested the establishment of medical malpractice courts to deal with the spiralling malpractice cases against doctors. ${ }^{[2]}$

The arguments for a different approach to criminal prosecutions of doctors for culpable homicide and calls for special malpractice courts seem to have been triggered by the acquittal of Dr Van der Walt by the Constitutional Court, because he had not received a fair trial when found guilty of negligently killing a child..$^{[3]}$

It is intended to indicate that the concerns raised by the doctors' organisations regarding culpable homicide and the call for separate medical malpractice courts are not warranted, because they may be dealt with by the present legislative framework and future practice directives, by using mediation and medical assessors instead.

The test for whether doctors should be criminally liable for culpable homicide should be based on gross negligence

In practice, very few doctors are charged criminally with culpable homicide. The law enforcement authorities accept that doctors usually do not intend to kill their patients, and health professionals are charged criminally only if their behaviour was intentional or a drastic departure from the standard of a reasonably competent practitioner in their field of practice. Intention is generally regarded as a separate concept from negligence, but the two may overlap when there is an intentional diversion from what a reasonably competent practitioner in the same field would have done in similar circumstances. ${ }^{[4]}$

It seems that for policy reasons, doctors are usually charged with culpable homicide - the negligent killing of a human being - and not murder. For instance, if the practitioner's conduct was reckless it may amount to 'eventual intention' which would justify a murder charge, ${ }^{[5]}$ but may not be prosecuted as such because of public policy - if it can be reframed as negligent rather than intentional conduct. ${ }^{[4]}$ In any event, if a mediation process is introduced before patients lay criminal charges or consult lawyers for malpractice (see below), better communication between the parties could result in a mutually acceptable solution.

\section{Doctors should not be held liable for mere errors of judgement}

In practice, doctors are not likely be held negligent for 'a mere error of judgement' - for instance, in the case of an emergency, if it is the type of error that a reasonably competent practitioner in their branch of the profession could make when faced with a similar situation. ${ }^{[6]}$ The confusion between an acceptable error of judgement and an error giving rise to a negligence claim could be overcome by requiring mediation before litigation. ${ }^{[7]}$ During mediation, the difference between mere errors of judgement and negligence could be clarified by the parties and used by them to achieve an equitable solution. The Chief Justice could direct all civil courts dealing with medical malpractice actions to require mediation before litigation. ${ }^{[8]}$ 


\section{Doctors are afraid to admit to patients that they have made an error}

Medical protection insurers have indicated that the failure of doctors to communicate with their patients after a procedure or treatment has gone wrong is one of the main reasons why patients sue their doctors. ${ }^{[9]}$ Mediation can be used to open lines of communication between doctors and their patients. The fear of making admissions that may result in litigation can be overcome by establishing prelitigation mediation facilities so that doctors, hospitals and patients can interact in order to come to an amicable solution, and avoid lawyers becoming involved. During a mediation to negotiate a settlement, admissions and statements may be made 'without prejudice' so that they cannot be used against the party making them. In any event, in civil matters, legislation provides that 'all disclosures and discussions, oral or written, made during mediation are confidential, and are inadmissible as evidence in any court, tribunal or other forum, unless recorded in the settlement agreement or otherwise disclosable in terms of the rules of court or other law.' ${ }^{\text {[10] }}$

\section{Doctors resort to defensive medicine out of fear of litigation and subject patients to unnecessary additional tests and treatment}

Doctors should focus on following good medical practice rather than resorting to 'unnecessary additional tests and treatment, ${ }^{[11]}$ as this may amount to unethical overservicing. ${ }^{[12]}$ The use of mediation in medical malpractice cases should help to reduce such a tendency, because the role of healthcare practitioners may be better understood by patients as a result of the mediation process.

\section{Malpractice claims are often for} unreasonably large amounts of damages An amendment has been made to the law to allow awards of damages to be made in instalments rather than in a lump sum. ${ }^{[13]}$ This change should help to reduce the number of exorbitant claims by lawyers, because it will impact on the amounts that they can recover for their clients, and charge for - especially if the full amount claimed will not be paid out for the period after the client has died. (In the past, lawyers have claimed damages for the period of the actuarially calculated future life expectancy of their clients that might not materialise in practice.) In any event, if such lawyers are pursuing claims that patently have no merit, or have been touting or 'ambulance chasing', their names and conduct should be reported to the Legal Practice Council for disciplinary action. ${ }^{[14]}$

\section{Special medical malpractice courts should be established, because magistrates lack the necessary skills to deal with the evidence}

The question of regional magistrates not having the necessary skills to weigh medicolegal evidence can be overcome by such magistrates appointing qualified medicolegal assessors to sit with them in medical malpractice trials. This can be done by presiding magistrates, if a magistrate 'deems it expedient for the administration of justice. [15] The courts have held that such a request may also be made by defence lawyers. ${ }^{[16]}$

A simple solution would be for the Chief Justice to issue a practice directive requiring all regional magistrates presiding in medical malpractice cases to appoint two assessors with knowledge of medical matters relevant to the case before them. ${ }^{[8]}$ Such medical assessors may outvote the presiding magistrate on findings of fact, but not on the application of the law. ${ }^{[17]}$

If regional magistrates sat with specialist medical assessors, it would not be necessary to establish separate malpractice courts presided over by medical experts. The presence of medical assessors could also help avoid what happened in the Van der Walt case, ${ }^{[3]}$ where the magistrate relied on textbook evidence. The medical profession, together with the Health Professions Council of South Africa, could assist the process by establishing a panel of assessors for use in in medical malpractice cases. This could be done without changes to legislation. The other remedial steps, particularly the requirement of pre-trial mediation, ${ }^{[4]}$ may substantially reduce the volume of such cases and allow for fewer delays.

\section{Conclusions}

Although the doctors' organisations have called for special legislation regarding the criminal charging of doctors for culpable homicide, and the establishment of special medical practice courts because of the huge increase in the number of medical malpractice cases, these issues can generally be dealt with by existing legislation and future practice directives to use mediation and medical assessors.

Judging by the scarce number of criminal prosecutions of doctors for culpable homicide, it appears that prosecuting authorities generally accept that doctors do not intend to kill their patients, and for policy reasons are only likely to charge them when there has been a very serious deviation from the standard of a reasonably competent doctor in their profession.

Doctors will generally not be held legally liable for mere errors of judgement if they are the kinds of errors that a reasonably competent practitioner in their field could make in similar circumstances.

Mediation before litigation could reduce the number of medical malpractice claims, and could be introduced as a requirement, without legislative intervention, by the Chief Justice issuing a practice directive requiring it to be implemented in all civil courts.

Doctors need not be afraid to make admissions during mediation proceedings before civil litigation, because if made while trying to negotiate a settlement, such admissions may be made 'without prejudice. Furthermore, legislation provides that such admissions and evidence may not be used in subsequent civil actions.

The Chief Justice could issue a practice directive stating that all presiding officers must appoint medical experts in the relevant field before the court as assessors in medical malpractice cases, and the medical profession could assist the process by arranging a panel of such experts who can be called upon to serve as assessors by the courts.

\section{Declaration. None.}

Acknowledgements. None.

Author contributions. Sole author.

Funding. National Research Foundation.

Conflicts of interest. None.

1. Medical Protection Society. Press release: South Africa healthcare leaders unite in call for review of culpable homicide law. 5 November 2021. https://www.medicalprotection.org/southafrica/casebookand-resources/news/news-article/2021/11/05/press-release-south-africa-healthcare-leaders-unite-incall-for-review-of-culpable-homicide-law (accessed 9 December 2021).

2. Medical Brief. SAMA calls for specialised courts to handle medico-legal cases. 1 December 2021. https://www.medicalbrief.co.za/sama-calls-for-specialised-courts-to-handle-medico-legal-cases/ (accessed 10 December 2021)

3. Van der Walt v S 2020 (2) SACR 371 (CC) paras 33 and 34.3

4. Cf. S v Ngubane 1985 (3) SA 677 (A).

5. Director of Public Prosecutions, Gauteng v Pistorius, 2016(1) SACR 431 (SCA) para 52

6. Neethling J, Potgieter JM, Visser PJ. Law of Delict. 4th ed. Durban: Butterworths, 2001:123-124, 146 
7. South African Law Reform Commission. Issue Paper 33. Project 141: Medico-legal claims, paragraph 6.8.6. 20 May 2017. https://www.justice.gov.za/salrc/ipapers/ip33_pri141_Medico-legal.pdf (accessed 3 December 2021)

8. National Government of South Africa. Office of the Chief Justice. Overview. https:// nationalgovernment.co.za/units/view/28/office-of-the-chief-justice-ocji (accessed 8 December 2021).

9. Huntington B, Kuhn N. Communication gaffes: A root cause of malpractice claims. Proc (Bayl Univ Med Cent) 2003;16(2):157-161. https://doi.org/10.1080/08998280.2003.11927898

10. Department of Justice and Constitutional Development, South Africa. Rules Board for Courts of Law Act 1985 (A 10707 1985). A Act, 1985 (A $\mathrm{No}$. Magistrates Courts of South Africa: Rule 80(1)(e). GN of 18 March 2014. Government Gazette No. rg10151_gon 183-rules-mc.pdf (accessed 16 January 2022).
2

Naidoo M. Doctors call for a re-look at medical negligence laws. Sunday Tribune, 28 November 2021. https://www.iol.co.za/news/doctors-call-for-a-re-look-at-medical-negligence-laws-ad2ba6f4-5f99-447a-

a627-4557e22e64ae (accessed 8 December 2021).
2. Health Professions Council of South Africa. Guidelines on Over-servicing, Perverse Incentives and Related Matters. Booklet 11. Pretoria: HPCSA, 2016. htttps://www.hpcsa.co.za/Uploads/Professional_Practice/ Conduct $\% 20 \% 26 \% 20$ thics/Bookle $\% 201 \% 20$ Guidelines\%200n\%20over $\% 20$ servicing $\% 20$ perverse $\% 20$ incentives\%20and\%20related\%20matters.pdf (accessed 6 December 2021 ).
13. Parliament of the Republic of South Africa. State Liability Amendment Bill (B16-2018): Section 2(a). https:// www.parliament.gov.za/bill/2291379\#: : text=To\%20amend\%20the\%20State\%20Liability,provide\%20

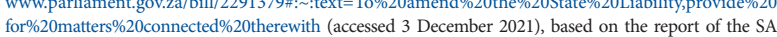
Law Reform Commission (para 6.7, sub para 3).

14. Legal Practice Act No. 28 of 2014: Section 3. https://www.gov.za/documents/legal-practice-act (accessed 6 December 2021).

15. Magistrates Courts Act 32 of 1944: Section 93 ter. https://www.justice.gov.za/legislation/acts/1944-032. pdf (accessed 6 December 2021)

16. Mukheiber v Raath 1999 (3) SA 1065 (SCA) para 32

17. Seekings J, Murray C. Lay Assessors in South Africa’s Magistrates' Courts. University of Cape Town, 1998:2-3. https://open.uct.ac.za/handle/11427/2457 (accessed 6 December 2021)

Accepted 14 January 2022. 